\title{
Good Corporate Governance And Bondholder-Shareholder Conflict: The Case Of Implementation Accounting Conservatism For Mining Company
}

\author{
Waluyo $^{1}$ \\ \{email: waluyo@mercubuana.ac.id ${ }^{1}$ \} \\ University of Mercu Buana, Jl. Raya Meruya- Jakarta Barat ${ }^{1}$.
}

\begin{abstract}
The application of Accounting Conservatism Principle can lead to different kind of assessment in various companies. Due to the application of this principle, financial statements are no longer considered as obligatory tools to evaluate company's risk. On the contrary, other parties state that the application of the Accounting Conservatism Principle can generate reasonable financial reports and provide relevance in Financial Information. The objective of this study is to analyze the effect of good corporate governance and bondholder-shareholder conflict against company accounting conservatism. The analysis of accounting conservatism is done using quantitative methods. In addition, data testing is done using classical assumption and hypothesis testing is conducted using multiple linear regression models. The level of accounting conservatism is measured using the value of accruals and the market value. The sample used is a mining company listed on the Indonesia Stock Exchange in 2014-2018. The results of the research show that each company implements accounting conservatism on a different level. In managerial ownership of accrual accounting, the effects of conservatism can be seen in several aspects; it is different from the approach in which the market value of managerial ownership did not affect the significance of accounting conservatism. Institutional ownership does not affect accounting conservatism when measured using accrual approach, but it has the effect on market value when measured. The presence of independent directors and market value when measuring accrual are able to influence the level of accounting conservatism.
\end{abstract}

Keywords: Good Corporate Governance, Bondholder-Shareholder Conflict, Political Cost, Accounting Conservatism. 


\section{Introduction}

The analysis of financial statements must generate relevant financial information. Thus, Accounting Conservatism is indeed necessary. With relevant financial information from financial statements, we are able to evaluate company's performance and we can predict various forms of risks in the future. In some cases of corporate scandals such as Enron Corporation, Xerox, WorldCom, financial reports generated by account becomes public concern. [1]

In principle, accounting conservatism is not a qualitative characteristic of conceptual framework. International Financial Reporting Standard (IFRS) does not use conservative principle in corporate accounting report in order to provide reasonable financial reports. [2] The higher the implementation of the Accounting Conservatism Principle by the company, the greater information asymmetry between financial report makers and of financial statements users. [3] This issue may potentially cause a great loss for uninformed investors. Thus, the principle of conservatism is not suitable with the objectives of modern accounting which requires accounting standards that can predict the condition of the company in the future. Financial accounting standards also provide a space for the application of accounting conservatism in terms of method selection, accounting estimation, and decision making. In the case of earnings management, companies that generate exceeded profits during last year's target are usually accounting practices that are less conservative. Conservatism can boost profits reported by company, but it can be categorized as an understatement or overstatement that will affect the earnings quality of. [4] Conservatism has an important role in the agency theory. In practice, the management applies conservative accounting policies by calculating high depreciation which will relatively lower profits permanently.

Lafond and Rouchowdhury [5] stated that managerial interests in the company could influence the method of financial recording, including the selection of a more conservative recording method. If the managers want to have better performance, companies tend to make non-conservative financial reports. The development of the business world and interrelated laws prompt managers to fill lawsuits by disadvantaged parties. [6] Managers tend to be more careful in providing financial statements that with conservative tendency.

Another reason that encourages managers to apply conservative accounting principles is the existence of Bondholder - Shareholder Conflict. This conflict happens when companies try to find funding source from debt. The practice of using debt as source of financing is called external financing. It is used by companies to finance their company's funding. [7] Companies must consider the size of the loan interest before considering creating debt. Fixed cost debt that has an impact on increasing financial leverage and the increasing uncertain return of debt to shareholders. Likewise, high dividend payments $t$ can threaten the interests of bondholders because they will reduce assets that should be used for repayment of debt, as a result the amount of dividends paid will be limited. [7]

A conflict of interest occurs when investors try to take advantage through excessive dividend payments. On the other hand, investors have an interest in the security of their investment funds. For companies in Indonesia, the existence of independent commissioners is part of the implementation of good corporate governance. The independent commissioner serves as an independent controller of the company's management performance.[8] Therefore, in carrying out their duties, independent commissioners need accurate, relevant and qualified information that employs more conservative accounting principles. Based on the phenomenon, the research aims to analyze the effect of Good Corporate Governance and Bondholder - Shareholder Conflict on the implementation of Accounting Conservatism. Given that, board of directors who are indecisively conducting supervision, companies tend to use accounting principles that are more aggressive or less conservative. 


\section{Literature Review}

Accounting Conservatism has an important role in conservative profits and assets arrangement. Thus, conservatism plays an important role in the agency theory. This theory is the basis that underlies company's business practices. This is due to the fact that conflict of interest occurring among shareholders and managers. Managers are obliged to manage resources, while principals have an obligation to provide rewards for company agents' tasks. This practice separates management functions and ownership functions which can lead to agency conflicts.[9] This agency relationship motivates individuals to be harmonious and keep their respective interests among the Manager and the Shareholders. [10]

Information asymmetry creates conflict between managers and shareholders and prompt companies to use others party for their own interests. The choice of conservatism method is inseparable from the interests of managers to optimize their interests at the expense of the interests of shareholders. [11] Due to the higher managerial ownership, management is not only an agent, but also the owner of company. This can reduce agency conflicts, and that is why companies tend to use conservative accounting.[5] If management has fewer shares than other investors, managers will tend to report higher profits, thus implementing a less conservative approach. When managers tend to report higher profits and have a larger managerial ownership, then the management inclines to report earnings more conservative. [12]

Conditional conservatism arises when lenders demand firms to recognize losses sooner than gains. Thus, lenders demand more conservatism to reduce their downside risk.[13] Risk uncertainty is reflected in the financial statements. [14] Financial statements that are based on prudent judgment will benefit financial statement users. [3]

The risk management role of accounting conservatism is also of relevant to the ongoing debates regarding the benefits, costs and continuing role of accounting conservatism as a central tenet of financial accounting.[15] Thus, conservatism is a pessimistic view in accounting, because accountants are pessimistic in facing uncertainty of profit or loss by using the principle to slowing down revenue recognition, accelerating recognition of costs, lowering valuation of assets and raising debt valuations. [14]

Managerial ownership structure reflects the percentage of shares held by management from all the shares in the company.[16] The choice of accounting methods is also influenced by managers. Ownership of managers determines policies and management choices regarding accounting methods including conservatives. [17]

Management with large ownership controls has a lower incentive to conduct self-serving behaviors that do not increase company value, so they tend to apply more conservative accounting to improve earnings quality. The greater management ownership, the management applies conservative accounting to increase firm value. [17]

The institutional ownership structure reflects the shares held by institutional parties of the total number of shares of the company. [16] Institutional ownership has the ability to control management through effective supervision to reduce earnings management actions. [12] In general, the mechanism of Good Corporate Governance can control management behavior. [18]

The ownership structure of institutional investors has a fairly large equity investment, can encourage supervisory actions on the performance of managers more stringent and can increase the value of the company. [12]

Board of Commissioners plays a very important role in the company, especially in the implementation of good corporate governance. [19] The Indonesia Stock Exchange issued a regulation requiring companies listed on the Indonesia Stock Exchange to appoint independent commissioners, with a minimum of $30 \%$ of all members of the board of commissioners. 
The bondholders-shareholders conflict arises when companies fund their operations from debt. High payment of dividends will threaten debt holder because it will reduce the assets available to repay the debt and overcome these problems. Generally, debt holder requires restrictions on dividend payments. [7] Conversely, the increase in corporate debt will reduce bondholders' claims on company assets. [20] Thus, debt holders will want a guarantee to minimum amount of net assets that is greater than the nominal value of the debt. Conservatism plays an important role in presenting conservative profits and assets. [21] Conservatism will limit the opportunistic behavior of managers or create profit distortions in presenting financial statement. [3]

Compared to smaller companies, large companies tend to use accounting methods that can reduce periodic profits. [22] Company size is a proxy for political aspects. Political cost arises from conflicts of interest among the company and the government. [23] The political economy might cause volatility when there is influence of governments who intervene in the market. Companies will implement more conservative accounting methods to present a stable earnings pattern or to prevent government intervention.[13] Firm size can also increase Political Cost. Companies with high performance standards and profitability will also increase Political Cost. In the context of Political Cost, accounting conservatism is implemented to reduce or delay payment of taxes. [23]

\subsection{Theoretical Framework and Research Development}

Based on the theory stated above, the following the Theoretical Framework and Research Development of this research.

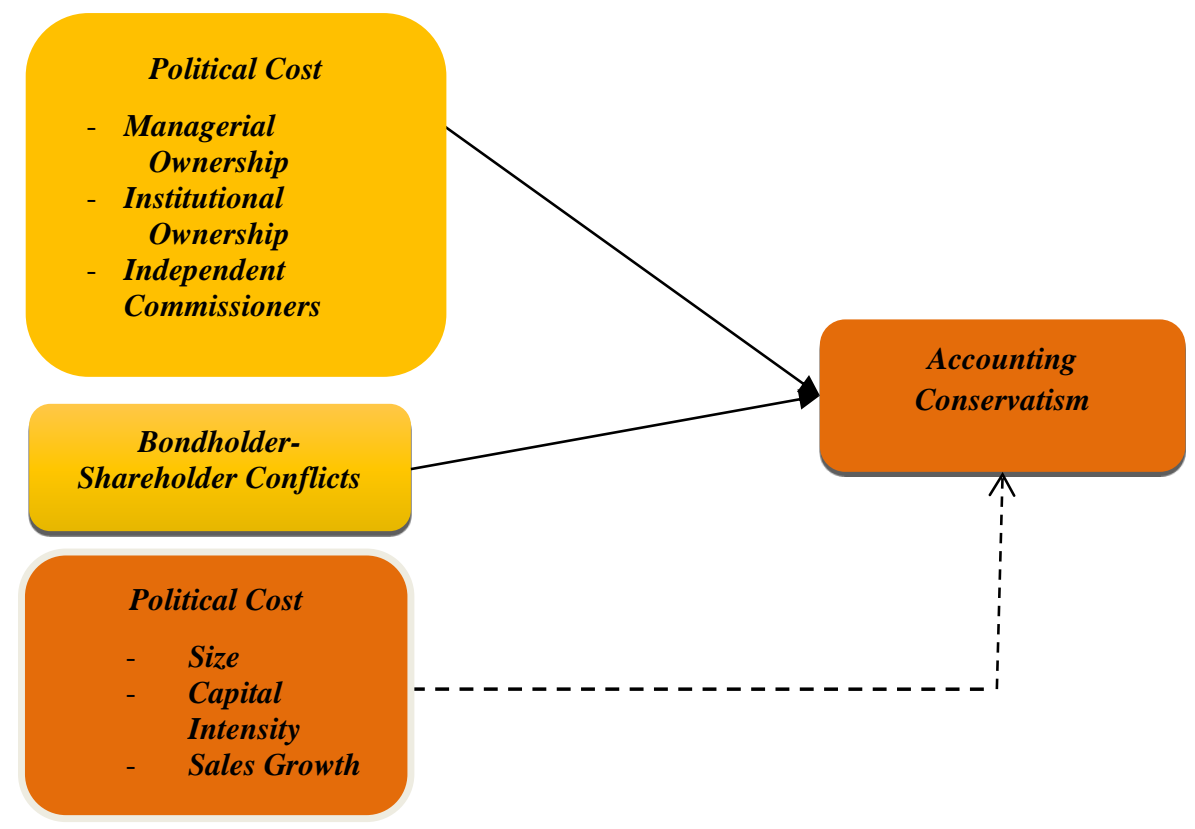

Fig. 2. Theoretical Framework

$\mathrm{H}_{1}$ : Managerial Ownership affects the Accounting Conservartism

$\mathrm{H}_{2}$ : Institusional Ownership affects the Accounting Conservartism

$\mathrm{H}_{3}$ : Independent Commisioners affects the Accounting Conservartism

$\mathrm{H}_{4}$ : Bondholder-Shareholder Conflict affects the Accounting Conservartism 


\section{Research Methodology}

This study employs the hypothesis analysis method, the objects of focus in observation are Good Corporate Governance (GCG), Bondholder-Shareholder Conflict and Accounting Conservatism in mining companies in Indonesia. This study will observe the direct effect between GCG and Bondholder-Shareholder Conflict as independent variables. Accounting Conservatism is used as an dependent variable, and Political Cost is used as control variable. The sample used in this study are mining sector companies listed on the Indonesia Stock Exchange (IDX) which publish their complete annual financial reports from 2014-2018. The Sampling Method t used in this study is purposive sampling of the mining sector which has a complete data of 25 companies and consistently published financial reports.

\section{Analysis and Result}

The following Table 1 shows the result of the descriptive statistical output from data processing.

Table 1. The Result of t-Test (Partial Test)

\begin{tabular}{|c|c|c|c|c|c|}
\hline \multirow{3}{*}{$\begin{array}{c}\text { Variabel } \\
\text { Independent }\end{array}$} & \multicolumn{2}{|c|}{ Dependen : } & \multicolumn{2}{|c|}{$\operatorname{ACCON~(1)~\& ~MKTCON~(2)~}$} & \multirow{3}{*}{ Simpulan } \\
\hline & \multicolumn{2}{|c|}{ Koefisien } & \multicolumn{2}{|c|}{ Sig. } & \\
\hline & ( 1 ) & ( 2 ) & ( 1 ) & (2) & \\
\hline (Constant) & 0,158 & $-2,195$ & 0,034 & 0,000 & - \\
\hline MANOWN & 0,001 & 0,002 & 0,029 & 0,520 & $\begin{array}{l}H_{p} \text { not accepted }(1) \\
H_{p} \text { accepted }(2)\end{array}$ \\
\hline INSOWN & 0,000 & 0,008 & 0,778 & 0,005 & $\begin{array}{l}H_{p} \text { accepted }(1) \\
H_{p} \text { not accepted (2) }\end{array}$ \\
\hline COMID & $-0,078$ & $-0,125$ & 0,031 & $0,076^{*}$ & $\begin{array}{l}H_{p} \text { not accepted }(1) \\
H_{p} \text { not accepted }(2)\end{array}$ \\
\hline LEV & $-0,143$ & 0,230 & 0,000 & 0,290 & $\begin{array}{l}H_{p} \text { not accepted }(1) \\
H_{p} \text { accepted }(2)\end{array}$ \\
\hline SIZE & $-0,005$ & 0,069 & 0,174 & 0,005 & $\begin{array}{l}H_{p} \text { accepted }(1) \\
H_{p} \text { not accepted (2) }\end{array}$ \\
\hline IM & 0,000 & 0,002 & 0,512 & $0,056^{*}$ & $\begin{array}{l}H_{p} \text { accepted }(1) \\
H_{p} \text { not accepted }(2)\end{array}$ \\
\hline SGROW & $-0,001$ & 0,002 & 0,021 & 0,465 & $\begin{array}{l}H_{p} \text { accepted }(1) \\
H_{p} \text { accepted }(2)\end{array}$ \\
\hline
\end{tabular}

*remark for level $10 \%$

\subsection{Hypothesis 1}

The test results in table 1 explain that the coefficient value obtained is 0.001 in the first model and 0.002 in the second model. The result of probability values is 0.029 in the first model and 0.520 in the second model. The positive coefficient value obtained in both models indicates that managerial ownership of the company has a positive effect on accounting conservatism in a mining company. The probability value of 0.029 in the first model where accounting conservatism is measured through accrual values is smaller than the $5 \%$ error rate, or $\alpha<0.05$. This states that the influence of the company's managerial ownership structure on accounting conservatism through accrual value in 
mining companies is significant. Thus, Hypothesis $\mathbf{1}$ is accepted in the first model. Whereas in the second model the alpha value is greater than the error rate of $5 \%$ and $10 \%$, or $0.520>0.005$. This indicates that the influence of managerial ownership structures on corporate accounting conservatism practices through market value is not significant.

\subsection{Hypothesis 2}

From the results of the t-test (partial) the coefficient value obtained is 0,000 in the first model and 0,008 in the second model. The probability value of 0,778 in the first model and 0,005 in the second model. Positive coefficient values indicate that the structure of institutional ownership in a mining company has a positive effect on accounting conservatism. In the first model the resulting probability value is greater than the $10 \%$ error rate, or $0.778>0.10$ states that the influence of institutional share ownership on accounting conservatism through accrual value is not significant. While the probability value on the second model of $0.005<\alpha 0.05$. This states that the influence of institutional share ownership on mining companies listed on the Stock Exchange in 2014-2017 against accounting conservatism in the company is significant, so Hypothesis $\mathbf{2}$ is accepted.

\subsection{Hypothesis 3}

From the results of the t-test (partial) the coefficient value obtained in the third hypothesis is -0.078 in the first model and -0.125 in the second model. The probability values for the two models are 0.031 and 0.076. The negative coefficient value states that the composition of independent commissioners in a company negatively affects accounting conservatism. In both models, the probability values produced are both smaller than the error rate of $5 \%$ and $10 \%$, or $0.031<0.05$ and $0.076<0.10$. This indicates that the influence of independent commissioners on accounting conservatism through accrual value or through market value is significant, so Hypothesis 3 is accepted.

\subsection{Hypothesis 4}

With the coefficient obtained for -0.143 in the first model and 0.230 in the second model with a probability value of 0.000 in the first model and 0.290 in the second model. The negative coefficient value in the first model indicates that the bondholder-shareholder conflict in mining companies has a negative impact on accounting conservatism, namely accrual value. Conversely, in the second model where the resulting coefficient value is 0.230 , it states that the resulting impact on bondholdershareholder conflicts is positive. In the first model the resulting probability value is smaller than the error rate of $1 \%$, or $0,000<0.01$ stating that the effect of conflict bondolder-shareholders on accounting conservatism through accrual values is significant, so Hypothesis $\mathbf{4}$ is accepted. While the probability value in the second model of $0.290>\alpha 0.10$. This suggests that the effect of bonholdershareholder conflict on mining companies on accounting conservatism is not significant..

\section{Conclusion}

Based on the results of research and analysis of mining companies listed in the Indonesia stock exchange managerial ownership accruals has an effect on the implementation of the Accounting Conservatism Principle. Thus, the management tends to increase company's value by implementing Accounting Conservatism Principle. Likewise, institutional ownership also affects the implementation of Accounting Conservatism based on market value. This shows that the Financial 
Report is indeed relevant. However, the Commissioners does not play a role according to their function as controllers in the company.

Taking everything into account, Bondholder - shareholder conflict will arise because of higher proportion of debt and risk. In the results of this study, it shows that the implementation of the accrual-based of Accounting Conservatism Principle is getting lower, thus companies have the tendency to perform earnings management.

\section{References}

[1] S. A. F. Deil, "Enron, Skandal Besar Perusahaan Energi yang Cekik Investor," Liputan 6, 2018. [Online]. Available: https://www.liputan6.com/bisnis/read/2031867/enron-skandal-besar-perusahaan-energiyang-cekik-investor. [Accessed: 03-Nov-2018].

[2] P. \& A. F. Andre, "Accounting Conservatism in Europe and the Impact of Mandatory IFRS Adoption : Do country, institutional and legal differences survive?," SSEC Bus. Sch. Cergy-Pontoise 95021 CEDEX, 2012.

[3] D. Mance, "Conservatism and Accounting Assymetry in International Accounting," pp. 1-10, 2012.

[4] J. P. and S. O. R. Amy Dunbar, "The Impact of The Bonus Depreciation Rules on The Ability of Defferd Tax Expense And Accrual-Based Measure To Detect Earnings Management Activities," in National Tax Association Proceedings, 2016, pp. 358-365.

[5] R. and R. L. W. LaFond, "The Information Role of Conservatism," Account. Rev., vol. 83, no. 2, pp. 447-478, 2008.

[6] R. Watts, "Conservatism in Accounting Part I: Explanations and Implications," Account. Horizons, vol. 17, no. 3, pp. 207-221, 2003.

[7] M. Stolt and T. Högnelid, "The Bondholder-Stockholder Conflict: The Relation between Debt Covenants and Bond Spreads," 2012.

[8] N. A. Amran and K. B. A. Manaf, "Board Independence and Accounting Conservatism in Malaysian Companies,” Procedia - Soc. Behav. Sci., vol. 164, no. December, pp. 403-408, 2014.

[9] M. Jensen and W. Meckling, "Theory of the firm: Managerial behaviour, agency costs and ownership," Strateg. Manag. J., vol. 21, no. 4, pp. 1215-1224, 1976.

[10] I. Muda, W. Maulana, H. S. Siregar, and N. Indra, "The analysis of effects of good corporate governance on earnings management in Indonesia with panel data approach," Iran. Econ. Rev., vol. 22, no. 2, pp. 599-625, 2018.

[11] M. Nakano, F. Otsubo, and Y. Takasu, "Effects of Accounting Conservatism on Corporate Investment Levels, Risk Taking, and Shareholder Value," IMES Discuss. Pap. Ser., vol. E, 2014.

[12] A. W. Latif, A. S. Latif, and F. Abdullah, "Influence of Institutional Ownership on Earnings Quality: Evidence for Firms Listed on the," Pakistan Bus. Rev., pp. 668-687, 2017.

[13] J. C. Hille, "Accounting conservatism: The Association Between Bondholder-Shareholder Conflicts Over Dividend Policy and Accounting Conservatism, The Effect on The Cost of Debt and The Influence of The Implementation of IFRS in 2005," Erasmus University Rotterdam, 2011.

[14] Sana'a, "The Effect of Accounting Conservatism on Financial Performance Indicators in the Jordanian Insurance Companies," J. Internet Bank. Commer., vol. 21, no. 1, pp. 1-17, 2016.

[15] G. C. Biddle, M. L. Z. Ma, and F. M. Song, "The Risk Management Role of Accounting Conservatism for Operating Cash Flows The University of Hong Kong The Risk Management Role of Accounting Conservatism for Operating Cash Flows," 2011.

[16] A. M. M. Hamdan, "The role of accounting conservatism in the relationship between ownership structure and firm performance," Int. J. Crit. Account., vol. 9, no. 5/6, p. 524, 2018.

[17] E. Murwaningsari and S. Rachmawati, "The Influence of Capital Intensity and Investment Opportunity Set toward Conservatism with Managerial Ownership as Moderating Variable," J. Adv. Manag. Sci., vol. 5, no. 6 , pp. 445-451, 2017.

[18] L. Santhanam, Navethitha; TJ Kamalanabhan; Dyaram, "Examining the moderating effects of organizational identification between human resource practices and employee turnover intention in Indian hospitality industry," J. Chem. Inf. Model., vol. 53, no. 9, pp. 1689-1699, 2013.

[19] A. Sekar, P. Prabowo, K. H. Titisari, and A. Wijayanti, "The Effect of Good Corporate Governance on Financial Performance of The Company," in The 2nd International Conference on Technology, Education, and Social Science 2018, 2018, pp. 167-175. 
[20] R. C. Nash, J. M. Netter, and A. B. Poulsen, "Determinants of contractual relations between shareholders and bondholders: investment opportunities and restrictive covenants," J. Corp. Financ., vol. 9, no. 2, pp. 201-232, 2003.

[21] M. Harakeh, E. Lee, and M. Walker, "Understanding How the Effects of Conditional Conservatism Measurement Bias Vary with the Research Context," SSRN Electron. J., no. 1997, pp. 1-39, 2019.

[22] W. Waluyo, "Firm size, firm age, and firm growth on corporate social responsibility in Indonesia: The case of real estate companies," Eur. Res. Stud. J., vol. 20, no. 4, pp. 360-369, 2017.

[23] M. J. Milne, "Positive accounting theory, political costs and social disclosure analyses: A critical look," Crit. Perspect. Account., vol. 13, no. 3, pp. 369-395, 2002. 